\title{
THE NATIONAL LEAGUE FOR WOMAN'S SERVICE
}

\section{By Mrs. Coffin Van Rensselaer,}

Vice-Chairman of the National League for Woman's Service.

To anyone who has watched the development of the war service of women volunteers in this country the credit for its volume and effectiveness must be given to the willingness and necessary energy rather than to the immediate efficiency. Probably never before in the history of American womanhood has there been a time when women have been so humble in their attitude to serve and so eager for work. We knew that in this country, no less than in England and France, the women were completely unprepared to meet the demand of a national call for trained woman power in the war emergency. Several months before the United States declared war on Germany, and when it already was apparent that our attitude of neutrality must end, women had begun to ask the question, What can we do? We knew, generally in a vague sort of way, that the English and French women were making their sacrifices and bearing their share of responsibility equally with the men, and through these sacrifices earning the respect and praise of all the nations of the civilized world.

First we asked the question among ourselves; then we asked the government, and when we learned that the government could not at that time give us any specific work, we created war jobs for ourselves by building up organizations among women for future service and by training in war activities to meet the demand for woman service which was bound to come. In other words, the women of America began to prepare. And so when war was declared thousands were ready for service,-a very small percentage at that,- - thousands more were creating their jobs, thousands were searching for the work they were to do, and still other thousands were asking the question, the old question, What can we do?

No better example of the willingness of the women volunteers is furnished than in the organization and growth of the National League for Woman's Service. When war was declared, the League had been organized two months. It was the first national war organization with a complete program and it attempted to solve the problem of the volunteer from every angle by classifying the neces- 
sary work in as many divisions so that any useful service offered by a woman might be advantageously employed under a standardized plan.

Three days before President Wilson was re-elected, Miss Grace Parker, the national commandant of the League, sailed for England to make an intensive study of the war work of Englishwomen, and with Miss Parker's sailing the League properly had its beginning. She went to England because she saw the war cloud hovering nearer and nearer this country, and felt the need of some plan of preparation for war among the great mass of untrained women whose power, properly directed, is one of the great national assets in modern warfare.

When Miss Parker returned, the plan and program-the same program on which the League today is being conducted-was presented at a session of the Congress for Constructive Patriotism, held in Washington on January 26, 1917, under the auspices of the National Security League. At a later session of over five hundred women delegates representing practically every section of the country, this program was approved, and the first meeting of the appointed organization committee was held the next day when temporary officers were elected. The officers elected were (and they still remain the same): Miss Maude Wetmore, chairman; Mrs. Coffin Van Rensselaer, vice-chairman; Miss Anne Morgan, treasurer; and Miss Grace Parker, national commandant, with a board of fifteen directors. Temporary state chairmen were appointed by the board, state chairmen to be elected by the members of given states at a meeting to be called after complete organization had taken place.

On February 4, the day following the dismissal of the German ambassador, the officers of the League met in New York City to put into immediate operation that part of the program which would be of the greatest usefulness at that time. Accordingly, an emergency program was prepared and the divisions of activity were classified as follows: Social and welfare (including the canteen, which has since become a separate division), home economics, agriculture, industry, motor driving, general service, home and overseas relief.

An information blank to be filled in by organizations of women indicating their willingness to coöperate in the work outlined in this emergency program, and also a membership enrollment blank for 
individuals desiring to enroll for specific service, were next prepared. And so on the day the United States declared war, the League had an enrollment of about 50,000 members, and an organization in thirty-one states. This had been accomplished in two months, not only by the sincere efforts of the officers of the League, but primarily because the women of the country were facing the crisis and demanding to be organized and prepared. The members are enrolled for a definite service and although they are not always classified as untrained workers, they render service in the particular branch of work they have designated. The League has now been organized in forty-one states in over seven hundred cities and has an enrollment of approximately 300,000 members.

During the eighteen months the United States has been at war the volunteers who make up the organization have accomplished many things. One of the first official acts was to have women included in the military census of New York State which at that time was impending. Through the efforts of the League, women, too, were included in the military census of Rhode Island, the only other state which has had a registration of its man power and woman power.

Following the organization of the League in Washington, several recommendations were made by the women to the federal government. One of these was that a Woman's Bureau be established under the government to deal with woman's work and woman's welfare. In making this recommendation, the League had in mind particularly the protection of the women who already were wageearners and the thousands of others who in the months to come would take up the work of the men gone to war, in the offices, factories and stores. A great army of these women in England since the outbreak of the war has been the main sustenance of the men at the front.

The plan of the Woman's Bureau was approved by Secretary Wilson, and the Bureau of Registration and Information was established in Washington in March, 1917, under the supervision of the secretary, but financed and operated by the League pending the time when the Department of Labor could take this work into the department. The following October the bureau, together with its staff of .workers and the organization which had been built up, was taken over by Secretary Wilson. But during the months that the 
bureau was under the guidance of the League, it had accomplished certain work, with the assistance of Secretary Wilson, which never ceased to be of value to the Department of Labor. A particularly valuable service was the survey of the labor situation, as it concerned women especially in the states which were engaged conspicuously in the filling of government war contracts. The states surveyed included Connecticut, Rhode Island, New Jersey, Maryland, Virginia, South Carolina, Delaware, Ohio, Indiana, Illinois, Michigan, New York and parts of Pennsylvania and Massachusetts. The survey listed generally the exact status of the woman labor supply in the factories engaged on war orders, the nature of the work the women did, the supply of trained woman labor in nearby towns and villages, the housing facilities in the community and other matters all important to effective work.

The urgency of this survey is shown in one instance. In Pennsylvania, a manufacturer to whom a war contract had just been given advertised for several hundred women workers. In answer to his advertisement, he received no more than half a dozen replies. The Pennsylvania chairman of the League heard of his experience and called upon him immediately to offer him the assistance of the Bureau of Registration and Information. And in a few days, with the aid of the survey already made by the bureau of Pennsylvania, the workers were furnished. Only a small part of the work of the Bureau of Registration and Information was done by volunteers, although it was a part of the emergency program. The bureau itself was a digression on the part of the League from its work of training volunteers; but it was such an important part of the program of woman's war service that it was included in the organization plans.

Two months after war was declared, the first social service club for soldiers and sailors was opened by the League in New York. The club was established under the auspices of the Social and Welfare Division and today there are a thousand or more similar clubs under various organizations in the United States. The club in New York City at first occupied the first floor of the national headquarters of the League. It now takes a whole building, an old Madison Avenue residence. There are game rooms, writing rooms, a library and various other comforts in this club. Fourteen rooms, which in no way meet the need, are reserved for sleeping accommodations 
for the men. The League club in San Francisco, from the latest reports, has the largest attendance. On one day this club was host to 3,000 men. Another club in Columbia, S. C., has a daily average attendance of over 1,000 men. In all its social and welfare work throughout the country the National League for Woman's Service has been working in close coöperation with the directors of the federal Commission on War Training Camp Activities.

One feature of the Sailors and Soldiers Clubs is the recreational canteen which is opened in them. In the canteens, substantial meals are served the men at prices very close to cost. The League is able to do this because all the workers from the cooks down to the dishwashers are volunteers. To women, the canteen has proved the most attractive of the volunteer work offered by the League. In New York City there are about 2,000 active workers in this branch of service. In addition to the League club the canteeners serve in all the war camp community clubs. Recently the Canteen Division in New York has been compelled to close its registration books to further applicants for service, when a checking up of workers showed a waiting list of 400 volunteers.

Every woman before she becomes eligible for service must take a course in cooking. The courses have been prepared by the League and cover practically all the small things she must know to give good service. The canteen undoubtedly sees more of the new spirit of willingness in women volunteers than any other division. In it there are women who, before the war, had never washed a dish or cooked a meal, and today they enjoy cooking hearty meals for hungry sailors and soldiers and then washing the dishes when the meal is finished.

One notable service of the eanteen occurred last summer in Detroit. The ration allowance per man is seventy-five cents a day. It was not possible for the men to find a satisfactory restaurant or lunch-room where three meals could be had for such a sum. The officers of this special detachment, after some investigation, contracted with the National League for Woman's Service canteen to furnish meals for the men for three weeks for the regular allowance. When the contract expired, the canteen had paid all their expenses, fed the men satisfactorily and had cleared nearly $\$ 1,000$. As a result of this service, Detroit as a city has contracted with the 
canteen to supply every enlisted man leaving the town with a lunch box at the cost of twenty-five cents. With the inauguration of the canteen, the League also organized the Emergency Canteen to meet the troop trains at the railroad stations after a long journey, and to feed the men on delayed trains where no provisions for feeding them had been made. The women who volunteered for this service pledged themselves to answer calls for service at any time of day or night. The Emergency Canteen built itself up to a membership of over 500 workers and recently has been taken over by the Red Cross, whose function it is to handle the railroad service.

In over 200 cities, the Home Economics Division of the League distributed thousands of the first and second Hoover pledge cards. This division, in practically every community where it is organized, made a house-to-house canvass to enlist the coöperation of the housewives with the Food Administration, to show them the methods of food conservation, and to see that households were put on a war-time food basis. All such work, we must remember, was and is being done by volunteers and the service they are giving to the government is the means of saving millions of dollars. Many classes in home economics have been formed by the League to train women to conserve food. An unusually successful, public-spirited part of the work of this division has been the establishing of community kitchens to help save food and fuel and to improve the general health of the centers in which they have been opened. At the community kitchens the cooking for the neighborhood in general is done. For a very small amount, a hot lunch or dinner can be bought at the kitchens and taken home. The Home Economics Division has opened kitchens in the neighborhoods where many women are compelled to leave their homes and work in factories or at other employment. Frequently these women are married and have not the time to give to the proper preparation of food for their families. The war, of course, necessarily has increased the number in this particular class of working women. In the majority of these kitchens the only paid worker is the cook; the dishwashers, waitresses and other helpers being volunteers.

Detachments under the Agricultural Division in every state in which the League is organized have promoted community gardens. Thousands of acres of land have been cultivated through the volunteers and they have made many unsightly vacant lots and useless 
backyards into war gardens. The women of the Agricultural Division have been responsible, too, for special courses in war gardening being introduced in the colleges. Since the formation of the Woman's Land Army the League has directed practically all of its agricultural work through this organization.

Recently the surgeon-general of the United States Army officially recognized the Motor Corps of the National League for Woman's Service, which since the organization of the League has been driving for the War Department, the army and navy, and various departments of the federal and state government engaged in war work. In common with the women leaders in English war work, the organizers of the League have always believed that motor driving was an essential job in which the women could release the much-needed men. The Motor Corps, when the first annual report of the League was compiled, had branches in more than seventy cities in the country. The members must have passed an examination in motor mechanics, as well as first aid and signalling. They are required to take military and sanitary drill and are in uniform. In the corps, the drivers not only give their time but their own cars and upkeep. The foreign service flag of the corps has nine service stars on it.

Every kind of volunteer from a Yiddish interpreter to an accountant has been furnished on call by the General Service Division. In this division are registered stenographers who work eight hours a day at a paying job and then give a few hours of their evenings for war service; bookkeepers who do the same; others who have volunteered for Red Cross, war savings stamps and liberty loan drives; linguists; office girls; and a thousand and one other miscellaneous workers. Some of the workers in the General Service Division are trained; others are not; but there is urgent and important work in many of the federal and state departments which does require trained workers. One of our branches lately has been asked to supply a young worker who speaks several languages to translate foreign news for the Committee on Public Information. The worker has been supplied. Volunteers in this division have, at times, been assigned the most menial work; but with only a minority of exceptions they have stuck to these jobs until they are successf ully completed.

The Home and Overseas Relief Division has sent thousands of 
garments, comfort kits, surgical dressings, sweaters and other knitted articles abroad. The business women of the country have been organized on a large scale for relief work after business hours by this division. The slogan of each worker is "A Garment a Week for France." At Christmas time, these women sent many huge boxes packed with garments and presents to France. For these Christmas boxes many of the women broke away from the making of the regulation garments, especially on the children's clothes. They embroidered and crocheted lace for some of the small dresses and then tucked five cents away in some of the little apron pockets. Lately this division, with the aid of 38,000 florists everywhere in the United States, has begun the distribution of flowers to the hospitals where there are sick and wounded men. The women, too, are meeting the returning hospital ships with flowers. This is a sentimental piece of war work, some will say, but few who have not taken these flowers personally to the hospitals can realize the joy it brings to the men, this "Say it with flowers."

It is not possible in so short a space to give even a rough outline of the many ramifications of the war work of the National League for Woman's Service. It was formed for service, whatever and wherever that might be, and coöperates actively with the Woman's Committee, Council of National Defense, the Commission on Training Camp Activities, Red Cross, Y. M. C. A., and Y. W. C. A., as well as the various branches of the government with which it works directly.

The League is founded on the fundamental principle that training to do our job well is an essential for efficient service, that this is no time for the square peg in the round hole, that the greatest patriotic service a woman can render her country is to do that thing which she can do best, in the environment which is most natural to her. Every twenty-four hours of the day must be spent in war service. The spirit which is put into the daily task transforms the common round into patriotic service; in the home, the training ground for the future citizens, and in the schools; in the industries, the second line of defense, and above all in the daily intercourse with our neighbors where we must each so live our ideals of democracy, not merely state them, that the women of the country shall form that solid foundation of a national morale without which we cannot have the sure victory. 